\title{
KONSEP EKONOMI PADA MASA RASULULLAH SAW
}

Oleh : Nela Novyanti (90100118098)

Islam merupakan sistem hidup yang sangat lengkap yang mengatur segala sendi kehidupan secara universal. salah satu diantaranya ialah dalam perekonomian. (Parakaasi, 2018). Ekonomi Islam pertama kali muncul pada saat rasulullah hijrah ke Madina. Mesikipun Rasulullah SAW. Lahir di mekah namun Awal mula munculnya ekonomi Islam baru bermula pada saat Rasulullah berhijrah ke Madinah. Ketika Rasulullah berada di Mekah beliau masih fokus untuk memperbaiki tauhid di Mekah yang itu sangat kacau misalnya penyembahan berhalah. Setelah sampai di Madinah dan telah menyelesaikan masalah politik dan konstituional, Rasulullah membentuk pemerintahan yang baru karena pada saat itu di Madinah hanya dipimpin oleh kepala-kepala suku saja ditiap daerahnya, yang paling terkenal adalah Aus dan Khasraj yang perekonomiannya ditopang oleh bidang pertanian. Namun, karena tidak adanya kas Negara untuk menjalankan pemerintahan akhirnya Rasulullah memutuskan untuk merumuskan sistem ekonomi yang berdasarkan pada prinsip dari ayat-ayat Al-Qur'an yang sesuai dengan ajaran Islam. (Karim, 2002)

Dalam upaya pembangunan pemerintahan di Madinah rasululullah kemudian membuat kebijakan-kebijakan yang digunakan untuk menghadapi permasalahan dalam kepemimpinan dan perekonomian. Terdapat dua kebijakanyeng dikeluarkan oleh rasululllah pada masa itu yakni, Kebijakan dalam moneter dan kebijakan dalam fiskal. Kebijakan moneter yang dibuat oleh beliau ialah dengan menciptakan sistem perekonomian yang bebas dari riba. Dimana pada saat itu riba sudah mengakar dalam kehidupan masyarakat. dengan cara memberikan pinjaman tanpa syarat serta pengeleloaan dana akat dan penerimaan Negara lainnya. Selain itu dilarang melakukan monopoli dengan penimbunan terhadap uang emas dan perak yang dapat mengakibatkan kesenjangan sosial. Sedangkan dalam kebijakan fiskal Pada masa rasululullah kemudian muncullah 
baitul mal sebagai lembaga fiskal yang diperkenalkan pada awal abad ke 7 Mesehi.yang berfokus pada infrastruktur, keagamaan, perangserta layanan kesejahteraan sosial. (Kharidatul, 2015).

Pelaksanaan kebijakan-kebijakan dan pemerintahan tersebut tentunya memerlukan kas yang dimana pada masa rasulullah sumber-sumber penerimaan Negara berasal dari Zakat, ushr (pajak), jizyah, kharaj, ghamimah dan fa'i. dari pendapat ini kemudian didapatkan sumber pengeluaran yang terdirti atas pengeluaran priemer yakni untuk upah, gaji pegawai, biaya pertahanan, biaya distribusi zakat dan ushr serta pembayaran utang. Adapun pengeluaran sekunder meliputi bantuan pendidikan, tunjangan kaum miskin dan pengeluaran sosial lainnya. (Kharidatul, 2015). 


\section{DAFTAR PUSTAKA}

Karim, Adiwarman. (2002) Sejarah Pemikiran Ekonomi Islam. Jakarta : The International Institute Of Islamic Thought (IIT).

Mudhiaah, Kharidatul. (2015). Sejarah Pemikiran Ekonomi Islam Masa Klasik. Vol 8, No 2.

Idris Parakasi, Kamiruddin. (2018) Analisis Harga dan Mekanisme Pasar dalam Perspektif Islam, Laa Maysir. Vol 5. No 1. 